(c) American Dairy Science Association, 2003.

\title{
Physical Properties of Cream Reformulated with Fractionated Milk Fat and Milk-Derived Components
}

\author{
L. L. Scott ${ }^{\star}$, S. E. Duncant, S. S. Sumnert, and K. M. Waterman† \\ *Archer Daniels Midland Co., Decatur, IL 62526 and \\ †Department of Food Science and Technology, Virginia Polytechnic Institute \\ and State University, Blacksburg 24061
}

\begin{abstract}
Emulsifying properties of milk-derived components influence the physical characteristics of reformulated creams. Fractionated butter oils with different melting ranges (low-melt: 10 to $25^{\circ} \mathrm{C}$; medium-melt: 25 to $35^{\circ} \mathrm{C}$ ) were recombined into fluid dairy systems using skim milk, or sweet buttermilk and butter-derived aqueous phase to manufacture $20 \%$ milk fat creams. Separation temperature $\left(49^{\circ} \mathrm{C}\right.$ or $\left.55^{\circ} \mathrm{C}\right)$ in obtaining emulsifying components was examined for its effect on physical properties of pasteurized reformulated creams. Rate of creaming, viscosity, feathering, and sensory characteristics of reformulated and natural creams stored at $3.3^{\circ} \mathrm{C}$ were evaluated over a 13 -d period. Creaming rate of reformulated and natural creams was unaffected by formulation and was most influenced by duration of storage. Melting characteristics of butter oils influenced viscosity at some shear rates. With the exception of natural cream, all formulations were consistent in apparent viscosity during the 2 -wk storage period. All creams feathered in a $\mathrm{pH}$ range of 4.70 to 5.20 and were classified as moderately stable to slightly unstable. All reformulated and natural creams met sensory quality specifications with the exception of creams formulated with skim milk and lower melting range butteroil. Creams formulated with buttermilk, butter-derived aqueous phase, and lower-melting range butter oil most closely mimicked natural creams with regard to sensory quality and viscosity.
\end{abstract}

(Key words: reformulated cream, physical properties, fractionated milk fat, milk-derived components)

\section{INTRODUCTION}

Milk fat can be separated to yield fractions with unique chemical, physical, and organoleptic character-

Received May 5, 2003.

Accepted June 13, 2003.

Corresponding author: S. E. Duncan; e-mail: duncans@vt.edu. istics. These fractions may be utilized in food applications to improve nutritional profile and increase the functionality of milk fat. Several methods of milk fat fractionation have been employed by the dairy industry to attain optimal crystallization behavior, polymorphism, melting range, and solid fat content for the particular application of interest (Kaylegian and Lindsay, 1995). Dry fractionation is the most common commercial method of milk fat fractionation (Kaylegian, 1995; Kaylegian and Lindsay, 1995). Low-melting milk fat fractions have a higher degree of unsaturated fatty acids than medium- and high-melting fractions, contributing to a lower melting point, softer texture, and greater potential for oxidation. Kaylegian and Lindsay (1992) produced cold-spreadable butter from low-melt, fractionated milk fat. The functionality of fractionated milk fat in oil-in-water emulsion systems has not been thoroughly investigated, and the question of how reformulated dairy products containing different milk fat fractions compare to natural dairy products remains unanswered.

Skim milk, sweet buttermilk, butter-derived aqueous phase, whey proteins, casein dispersions, phospholipids, and purified milkfat globule membrane suspensions have been used successfully to emulsify butter oil (Oortwijn and Walstra, 1979; Tomas et al., 1994; Elling et al., 1996; McCrae et al., 1999). Processing parameters, fat content, temperature, and storage conditions influence emulsion stability and viscosity of dairy systems (Phipps, 1982; Langley, 1984; Prentice, 1992; Elling and Duncan, 1996). Yamauchi et al. (1982) found that creaming stability of ultra heat-treated milk decreased, and formation of a cream plug occurred during the first month of storage. Melsen and Walstra (1989) determined that creams formulated with skim milk and anhydrous milk fat (5 to $30 \%$ ) were less susceptible to coalescence and clumping than natural creams. Neither quiescent storage nor flow field changed fat globule size distribution or fat content in recombined creams, indicating that recombined fat globules were very stable to partial coalescence when compared with natural creams. Reformulated creams homogenized at 13.6/3.4 
$\mathrm{MPa}$ were more stable than similar creams homogenized at 10.2/3.4 MPa; however, a decrease in emulsion stability of creams homogenized at both pressures was evident by d 7 of storage (Elling and Duncan, 1996). Wibley (1992) and Lee and Sherbon (2002) suggest that emulsion stability increases with increasing viscosity.

Cream is a colloidal dispersion that displays nonNewtonian behavior (inverse relationship between apparent viscosity and shear rate, or hysteresis) at high fat contents and/or storage temperatures below $40^{\circ} \mathrm{C}$ (Fox and McSweeney, 1998). An increase in fat level has been found to increase apparent viscosity of cream while increasing temperatures result in a decrease in cream viscosity (Prentice, 1972). Conversely, Jeurnink and DeKriuf (1993) demonstrated an increase in the viscosity of skim milk when heated to $90^{\circ} \mathrm{C}$. After holding skim at $90^{\circ} \mathrm{C}$ for $450 \mathrm{~s}$, a plateau value in viscosity was reached, which was explained as the completion of whey protein denaturation. Lee and Sherbon (2002) found that heating $\left(80^{\circ} \mathrm{C}\right.$ for $\left.3 \mathrm{~min}\right)$ or homogenization alone did not increase the viscosity of whole milk, but combined treatments of heating and homogenization significantly increased viscosity compared to the viscosity of raw milk. Prentice (1992) demonstrated an increase in apparent viscosity due to homogenization that was attributed to protein adsorption to lipid globules and formation of homogenization clusters. Elling and Duncan (1996) found higher apparent viscosities in reformulated creams than in natural creams, but viscosity of these cream types was unaffected by homogenization pressure.

Homogenization, with the resultant increase in fat globule surface area, typically stabilizes the cream emulsion but can cause cream feathering under acidic or heat conditions. Feathering is a quality defect of cream characterized by formation of undesirable particulates upon addition of cream to coffee (Towler, 1982; Fox and McSweeney, 1998). Homogenized creams are more susceptible to feathering than nonhomogenized creams because newly adsorbed proteins from the homogenization process destabilize and flocculate with fat globules (Geyer and Kessler, 1989). Destabilization and flocculation result from the heat and acidity associated with coffee. Because temperature and acid content of coffee is influenced by factors such as coffee type, method of processing, and hardness of the water used in making coffee, researchers developed standard parameters for heat $\left(80^{\circ} \mathrm{C}\right)$ and acidity $(\mathrm{pH} 4.75)$ for measurement of feathering (Geyer and Kessler, 1989). Feathering has been shown to occur in reformulated and natural creams in a pH range of 4.86 to 5.09, regardless of formulation, homogenization pressure, and length of storage (Elling and Duncan, 1996).
In the present study, $20 \%$ milk fat cream was manufactured with skim milk or sweet buttermilk and butterderived aqueous phase as emulsifiers for low- and medium-melting modified butter oils. Creams formulated from fractionated butter oils and milk-derived components were analyzed over $2 \mathrm{wk}$ of refrigerated storage for creaming stability, viscosity, and feathering and compared with natural creams. Flavor quality of creams was evaluated by an experienced sensory panel. Implications of separation temperature in obtaining components (skim milk, buttermilk, butter-derived aqueous phase) and melting point characteristics of butter oil on the physical properties of formulated creams were also examined.

\section{MATERIALS AND METHODS}

\section{Separation into Cream and Skim Milk}

Raw milk obtained from the Virginia Tech dairy farm was separated into 30 to $35 \%$ milk fat cream and skim milk with a pilot plant separator (Elecrem separator, model 1G, 6400 rpm, Bonanza Industries, Inc., Calgary, Alberta, Canada). Creams, obtained at separation temperatures of 49 or $55^{\circ} \mathrm{C}$, were standardized to 30 to $33 \%$ milk fat using skim milk obtained from the appropriate separation. Each cream was vat pasteurized at $68.3^{\circ} \mathrm{C}$ for $30 \mathrm{~min}$, cooled to $13^{\circ} \mathrm{C}$ in an ice bath, refrigerated $\left(3.3^{\circ} \mathrm{C}\right)$, and subsequently used for preparation of buttermilk.

\section{Preparation of Buttermilk and Butter-Derived Aqueous Phase}

Sweet buttermilk is obtained from cream by the process of churning. It contains milk fat globule membrane fragments rich in surface-active agents (proteins and phospholipids) that are released during churning. When butter is melted, remaining milk fat globule membrane on the fat globule surface is released into the butter-derived aqueous phase. The aqueous phase of butter differs from buttermilk in that it has 2 to 3 times the lipid content of buttermilk (Deeney et al., 1985; Keenan and Patton, 1993; Elling et al., 1996).

Sweet buttermilk was obtained as described by Elling et al. (1996). Cream (30 to $33 \%$ milk fat) obtained at separation temperatures of $49^{\circ} \mathrm{C}$ or $55^{\circ} \mathrm{C}$ was tempered to $13^{\circ} \mathrm{C}$. Sweet buttermilk and butter were derived from cream by mechanical churning (Gem Dandy Standard Electric Churn, Bonanza Industries, Inc., Calgary, Alberta, Canada). Butter granules were removed from sweet buttermilk by straining through cheesecloth.

Commercially produced (Grassland Dairy Products, Inc., Greenwood, WI) butter-derived aqueous phase was obtained from $38.5 \%$ milk fat cream pasteurized at 
Table 1. Description of natural and reformulated creams containing $20 \%$ milk fat.

\begin{tabular}{ll}
\hline Cream formulation & Separation temperature $^{1}$ \\
\hline $80 \%$ Skim $+20 \%$ low-melt butter oil & \\
$80 \%$ Skim $+20 \%$ low-melt butter oil & $49^{\circ} \mathrm{C}$ \\
$80 \%$ Skim + 20\% medium-melt butter oil ${ }^{2}$ & $55^{\circ} \mathrm{C}$ \\
$70 \%$ Buttermilk + 20\% low-melt butter oil $+10 \%$ aqueous phase & $55^{\circ} \mathrm{C}$ \\
$70 \%$ Buttermilk + 20\% low-melt butter oil $+10 \%$ aqueous phase & $49^{\circ} \mathrm{C}$ \\
$70 \%$ Buttermilk + 20\% medium-melt butter oil $+10 \%$ aqueous phase & $55^{\circ} \mathrm{C}$ \\
$20 \%$ Natural cream & $55^{\circ} \mathrm{C}$ \\
$20 \%$ Natural cream & $49^{\circ} \mathrm{C}$ \\
\hline${ }^{1}$ Temperature used to obtain skim and buttermilk. & $55^{\circ} \mathrm{C}$ \\
${ }^{2}$ Obtained from Wisconsin Center for Dairy Research; low-melt butter oil: dropping point $18^{\circ} \mathrm{C}$; medium- \\
melt butter oil: dropping point $26^{\circ} \mathrm{C}$. \\
${ }^{3}$ Commercially obtained from Grassland Dairy Products, Inc., Greenwood, WI.
\end{tabular}

$85.6^{\circ} \mathrm{C}$. After pasteurization, the cream went through a two-stage commercial separation process. Serum or aqueous phase was recovered following separation.

Skim milk, sweet buttermilk $\left(49^{\circ} \mathrm{C}\right.$ and $55^{\circ} \mathrm{C}$ separation), and commercially obtained butter-derived aqueous phase were pasteurized in a tubular heat exchanger (Microthermics UHT/HTST Lab 25-HV, Microthermics, Inc., Raleigh, NC) at $71.7^{\circ} \mathrm{C}$ for $15 \mathrm{~s}$, cooled, and stored at $3.3^{\circ} \mathrm{C}$ until reformulation.

\section{Characterization of Low-Melt and Medium-Melt Fractionated Butter Oils}

Low-melt and medium-melt fractionated butter oils were obtained from anhydrous milk fat utilizing the Tirtiaux fractionation procedure at the Wisconsin Center for Dairy Research (University of Wisconsin, Madison). Percentage of solid fat was zero at approximately $25^{\circ} \mathrm{C}$ and $30^{\circ} \mathrm{C}$ for low-melt and medium-melt fractions, respectively. Both butter oils were described as having butter-like flavors and medium-yellow coloration. Lowmelt fraction butter oil had a dropping point of $18^{\circ} \mathrm{C}$, whereas medium-melt fraction butter oil had a dropping point of $26^{\circ} \mathrm{C}$ (Kaylegian, 1998).

\section{Cream Reformulation}

Creams (20\% milk fat) were formulated from lowor medium-melt fractionated butter oil, skim milk, or buttermilk obtained at a separation temperature of $49^{\circ} \mathrm{C}$ or $55^{\circ} \mathrm{C}$, and commercially obtained butter-derived aqueous phase. Butter oils were melted at 45 to $50^{\circ} \mathrm{C}$ prior to reformulation. Natural creams were obtained by separation at $49^{\circ} \mathrm{C}$ or $55^{\circ} \mathrm{C}$ into 30 to $33 \%$ milk fat cream and skim. Skim milk from the appropriate separation was used to standardize each natural cream to $20 \%$ milk fat. Creams were preheated to $55^{\circ} \mathrm{C}$, homogenized (APV Gaulin, Inc., model 15MR, Everett, MA) in two stages (13.6/3.4 MPa), cooled to $29.4^{\circ} \mathrm{C}$, and pasteurized at $77.8^{\circ} \mathrm{C}$ for $15 \mathrm{~s}$ in a tubular heat exchanger (Microthermics UHT/HTST Lab 25-HV, Microthermics, Inc.). Table 1 describes cream formulations.

\section{Creaming Stability}

Emulsion stability of each cream was analyzed for rate of creaming over 2 wk of storage. On the day of formulation (d 0), creams were packaged in 100-ml graduated cylinders, capped, and stored at $3.3^{\circ} \mathrm{C}$. Initial fat content was determined and fat content of the top and bottom portion of each cream was analyzed in duplicate on $\mathrm{d} 1,3,5,7,9,11$, and 13 of storage using a modified Babcock procedure (Marshall, 1993). Change in fat percentage of each layer during storage was determined by dividing the fat content of the top or bottom layer by the initial fat content of the cream and multiplying the number by 100 . The difference between this number and 100 is the change in percentage of fat.

\section{Viscosity}

Viscosity measurements were made on $\mathrm{d} 1,7$, and 13 of storage. On the day of formulation, 15-ml samples of each cream were packaged and stored at $3.3^{\circ} \mathrm{C}$. Measurements were made with a Haake Rotovisco RV-12 viscometer equipped with a Haake NV spindle and cup (Haake-Buchler Instruments, Paramus, NJ). A Haake A82 cooling unit maintained a constant temperature of $7^{\circ} \mathrm{C}$, at which all measurements were taken. Shear stress measurements were taken at the following shear rates and $40 \mathrm{~s}$ was allowed to elapse between readings (shear rates $\left(\mathrm{s}^{-1}\right)$ : 173, 346, 692, 1385, 2770, 1385, 692, $346,173)$. Viscosity was determined by dividing shear stress readings by shear rate.

\section{Feathering Stability}

The feathering assay is a visual test that utilizes eleven heated $\left(85^{\circ} \mathrm{C}\right)$ sodium acetate buffers $(0.012 \mathrm{M})$ 
Table 2. Flavor defects associated with cream products. ${ }^{1}$

\begin{tabular}{lll}
\hline Off-flavor & Cause & Flavor description \\
\hline Light-induced oxidized & Exposure to sunlight or fluorescent light & Cardboard or paperboard \\
Oxidized & Oxidation of unsaturated fatty acids in milk fat & Cardboard, tallow, metallic, or oily \\
Rancid & Lipase hydrolysis of milk fat triglycerides to free fatty acids & Butyric or soapy \\
Cooked & Exposure of hydrogen sulfide $\left(\mathrm{H}_{2} \mathrm{~S}\right)$ groups in whey proteins & Cooked, heated, or caramelized \\
& as a result of pasteurization & Watery or flat \\
Flat & Lack of aroma or fat & Old or stale \\
Lacks freshness & Product is near the end of shelf-life & Malt \\
Malty & Growth of Streptococcus Lactis & Fruity flavor, particularly strawberry \\
Fruity & Growth of Pseudomonas Fragi &
\end{tabular}

${ }^{1}$ Panelists were trained to recognize the listed off-flavors that may occur in cream.

ranging in $\mathrm{pH}$ value from 4.70 to 5.60 . Feathering is characterized by visible flocs of any size that are evident after standing for 2 to $3 \mathrm{~min}$. The feathering test was conducted on $\mathrm{d} 1,7$, and 13 of storage. On the day of formulation ( $\mathrm{d} 0$ ), cream samples were transferred into test tubes, capped, and stored at $3.3^{\circ} \mathrm{C}$. The assay was performed as described by Anderson et al. (1977). Scores ranging from 5 to 0 to -5 were used to assess the degree of feathering in each sample. The lowest buffer $\mathrm{pH}$ at which feathering failed to occur was recorded as the feathering score. Highly stable creams are typically denoted by scores of 5,4 , or 3 (pH 4.70 , 4.75 , or 4.81 , respectively), whereas stable creams are given feathering scores of 2 or 1 ( $\mathrm{pH} 4.86$ or 4.92). Moderately stable creams have feathering scores of $0 \mathrm{pH}$ 5.00) and slightly unstable creams are assigned feathering scores of -1 or -2 ( $\mathrm{pH} 5.09$ or 5.20). Creams with feathering scores of $-3,-4$, or $-5(\mathrm{pH} 5.31,5.45$, or 5.60 , respectively) are unstable and considered to be unmarketable to consumers (Atherton and Newlander, 1977).

\section{Sensory Evaluation of Cream Quality}

Microbiological analyses (for enumeration of aerobic, psychrotrophic, and coliform bacteria) were conducted prior to sensory evaluation to ensure that creams were sufficiently pasteurized and low in spoilage bacteria. Creams were evaluated for sensory characteristics within the first $4 \mathrm{~d}$ of refrigerated storage at $3.3^{\circ} \mathrm{C}$. Experienced panelists $(n=12)$, selected based on past participation in dairy sensory activities, used the In/ Out Method of Specification to determine if the creams met quality specifications with regard to flavor (Munoz et al., 1992). Training sessions (one per replication) were conducted $1 \mathrm{wk}$ prior to each panel. During each training session, panelists were familiarized with the In/Out Method of Specification, as well as with potential flavor defects (light oxidized, rancid, cooked, flat, lacks freshness, malty, and fruity) associated with cream products (Table 2). Samples were considered "In" speci- fication if "slight" off-flavors were detected since cream is very susceptible to biochemical degradation (oxidation, lipolysis, etc.) and microbial contamination (fruity, malty, etc.). However, as off-flavors reached moderate levels, creams were deemed "Out" of specification. Creams were designated acceptable in quality if $65 \%$ of the responses were "In" specification.

Samples were identified with three-digit codes and randomized for presentation to panelists. Panelists were seated in individual booths with controlled lighting in the sensory laboratory of the Department of Food Science and Technology at Virginia Tech. Panelists were given a total of eight samples $(20 \mathrm{ml}$ presented in 28.35-gm portion-size plastic soufflé cups), one sample per cream formulation. Sample temperature was maintained at $4 \pm 3^{\circ} \mathrm{C}$ during sensory evaluation.

\section{Statistical Analyses}

Effect of separation temperature in obtaining components, formulation, and melting range characteristics of butter oil on physical properties and sensory quality of reformulated and natural creams was determined. Creaming stability, viscosity, feathering, and sensory characteristics were analyzed for three replications. Creaming stability, viscosity, and feathering tests were performed in duplicate within each replication. Results from the feathering assay were ordinal data and not statistically analyzed. Sensory evaluation responses from all replications were combined and analyzed as percentage values. A split plot design was used for analysis of data generated from creaming stability and viscosity testing. Statistical contrasts were used to compare skim milk creams to buttermilk creams, buttermilk creams to natural creams, and natural creams to skim milk creams. Creams processed from components obtained at $49^{\circ} \mathrm{C}$ were compared to creams manufactured from components obtained at $55^{\circ} \mathrm{C}$. Creams formulated with low-melt fraction butter oil were statistically compared to creams formulated with mediummelt butter oil. A $P$-value of 0.01 was used to determine 
Table 3. Creaming stability (percentage of change in fat content of top and bottom layer) of natural and reformulated creams.

\begin{tabular}{|c|c|c|c|c|}
\hline \multirow{2}{*}{$\begin{array}{l}\text { Formulation } \\
\text { (separation temperature) }\end{array}$} & \multirow{2}{*}{$\begin{array}{l}\text { Percentage } \\
\text { of increase } \\
\text { in fat }{ }^{1} \\
\text { Top }\end{array}$} & \multirow{2}{*}{$\begin{array}{l}\text { Percentage } \\
\text { of decrease } \\
\text { in fat }^{1}\end{array}$} & \multicolumn{2}{|c|}{ Day of significance } \\
\hline & & & Top & Bottom \\
\hline $80 \%$ Skim $+20 \% \operatorname{lmbo}^{2}\left(49^{\circ} \mathrm{C}\right)$ & 21.1 & 22.7 & 9 & 5 \\
\hline $80 \%$ Skim $+20 \% \operatorname{lmbo}\left(55^{\circ} \mathrm{C}\right)$ & 9.5 & 16.2 & 9 & 5 \\
\hline $80 \%$ Skim $+20 \% \mathrm{mmbo}^{3}\left(55^{\circ} \mathrm{C}\right)$ & 12.0 & 12.4 & 7 & 5 \\
\hline $70 \% \mathrm{bm}^{4}+20 \% \operatorname{lmbo}+10 \% \mathrm{ap}^{5}\left(49^{\circ} \mathrm{C}\right)$ & 14.1 & 19.0 & 13 & 5 \\
\hline $70 \% \mathrm{bm}+20 \% \mathrm{lmbo}+10 \%$ ap $\left(55^{\circ} \mathrm{C}\right)$ & 12.1 & 16.4 & 11 & 3 \\
\hline $70 \% \mathrm{bm}+20 \% \mathrm{mmbo}+10 \%$ ap $\left(55^{\circ} \mathrm{C}\right)$ & 15.4 & 17.7 & 11 & 1 \\
\hline Natural cream $\left(49^{\circ} \mathrm{C}\right)$ & 18.9 & 17.1 & 9 & 1 \\
\hline Natural cream $\left(55^{\circ} \mathrm{C}\right)$ & 11.5 & 17.0 & 13 & 1 \\
\hline Standard error & 1.715 & 1.646 & & \\
\hline
\end{tabular}

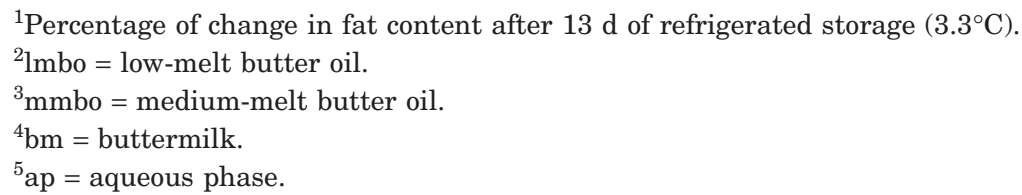

significance in order to minimize chance of Type 1 Error. Statistical analyses were conducted using SAS (Cary, $\mathrm{NC})$.

\section{RESULTS AND DISCUSSION}

\section{Emulsion Stability}

Processing techniques and content of surface-active components, such as proteins and phospholipids, affect emulsion stability and physical properties of creams. Proteins, particularly caseins, tend to associate with lipid globules at pasteurization temperatures. Creaming associated with milk fat emulsions can be delayed when heat processing halts cold agglutination (McPherson et al., 1984; Houlihan et al., 1992; Kim and JimenezFlores, 1995). A decrease in creaming stability is noted by the formation of a cream plug at the surface of the milk fat emulsion. Over time, milk fat progressively rises to the top of the emulsion, whereas the denser skim phase remains at the bottom. Creaming rate (measured as an indicator of emulsion stability) of reformulated and natural creams was not significantly $(P>$ 0.01) affected with regard to formulation, separation temperature used in obtaining components, or melting range characteristics of the butter oils (Table 3). Twostage homogenization at a pressure of $13.6 \mathrm{MPa}$ followed by $3.4 \mathrm{MPa}$ yielded moderately stable creams. Elling and Duncan (1996) found this higher homogenization pressure to be more efficient in yielding stable creams than a lower homogenization pressure of $10.2 /$ 3.4 MPa.

During storage, all creams displayed a decrease in creaming stability, denoted by an increase in percent fat of the top layer and a decrease in fat content of the lower layer of the emulsion. Length of storage significantly $(P \leq 0.01)$ influenced creaming stability as determined by the fat content of the top and bottom layers. Significant $(P \leq 0.01)$ differences in creaming stability were detected in the bottom layer earlier in storage ( $d$ 3 to 5) than in the top layer (d 7 to 13), indicating that some interaction may have occurred between the top and bottom layers of the emulsions. After $13 \mathrm{~d}$ of refrigerated storage, the total percentage of change in fat of the top layer ranged from $9.5 \%$ for cream formulated with low-melt butter oil and skim $\left(55^{\circ} \mathrm{C}\right.$ separation temperature) to $21.1 \%$ for cream formulated with low-melt butter oil and skim $\left(49^{\circ} \mathrm{C}\right.$ separation temperature). Over the entire 13-d storage period, creams manufactured from components obtained at a $55^{\circ} \mathrm{C}$ separation temperature generally were more stable than those containing components from the $49^{\circ} \mathrm{C}$ separation temperature. Utilization of a higher separation temperature could have contributed to more efficient separation of components and inactivation of cold agglutination. Natural creams formulated from components obtained at the $55^{\circ} \mathrm{C}$ separation temperature and creams containing skim (obtained at the $55^{\circ} \mathrm{C}$ separation temperature) tended to be more stable than the other formulations when considering the entire storage period. Formulations containing buttermilk/aqueous phase and natural cream $\left(55^{\circ} \mathrm{C}\right.$ separation) remained stable for a longer time during storage, as indicated by a later day of significance for change in fat content of the top layer as compared to creams formulated with skim. The better stability to creaming associated with these creams can be attributed to the presence of more native milk fat globule constituents, such as phospholipid materials 


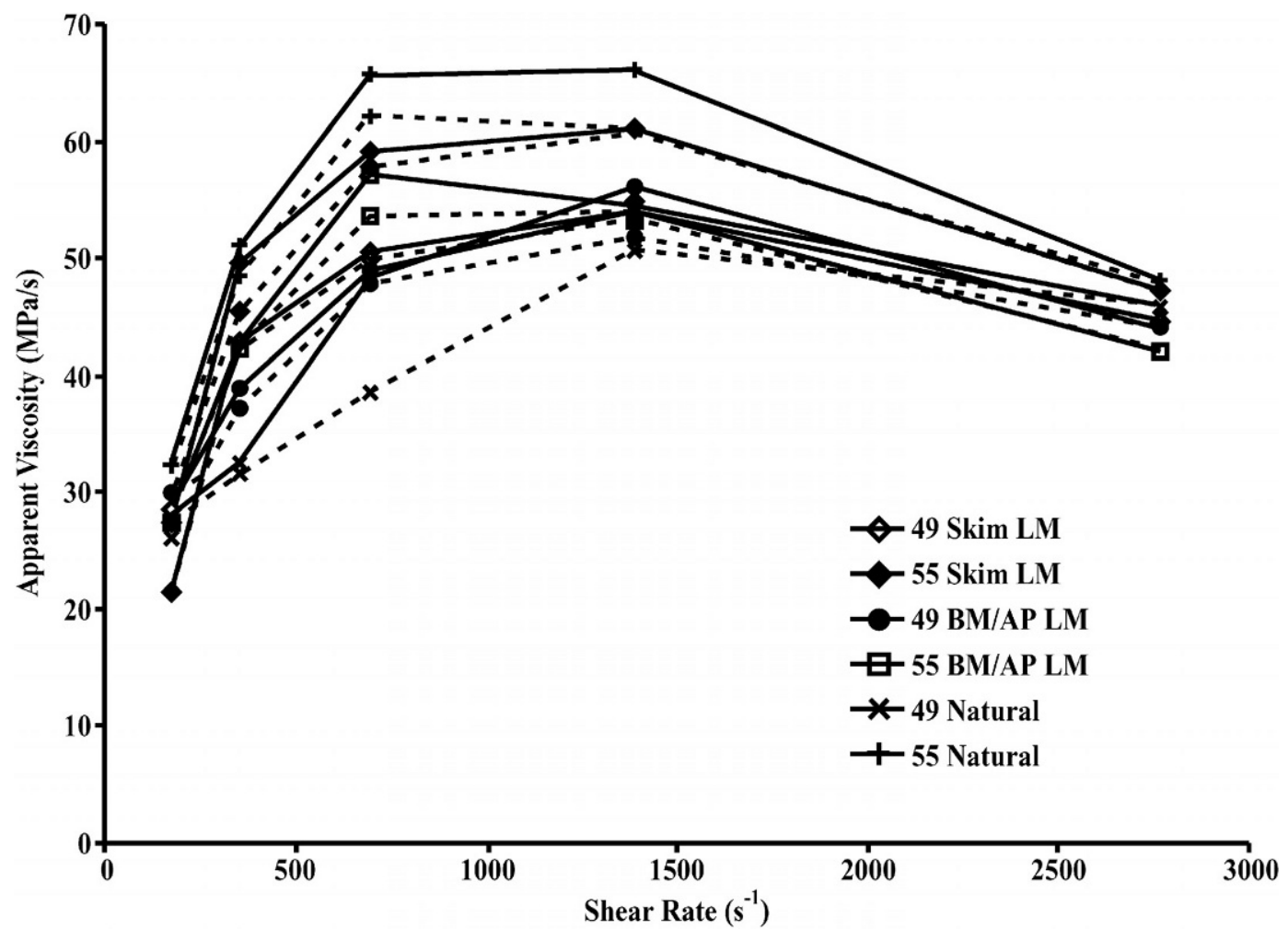

Figure 1. Effect of component ( $\mathrm{BM}=$ buttermilk; $\mathrm{AP}=$ aqueous phase) separation temperature $\left(49\right.$ or $\left.55^{\circ} \mathrm{C}\right)$ on apparent viscosity of natural creams and creams containing low-melt (LM) butter oil $\left(\mathrm{d} 1 ; 7^{\circ} \mathrm{C}\right)$ ( - increasing shear; --- decreasing shear).

that remain after the churning process. Natural creams and creams containing buttermilk and butter-derived aqueous phase have been found to contain higher levels of total phospholipids and phospholipids occurring in the surface material associated with lipid globules than creams formulated with skim (Elling et al., 1996; Scott, 1999). Phospholipid content in butter-derived aqueous phase has been found to be over forty times higher than in skim milk, and sweet buttermilk contains over seven times more phospholipid than does skim milk (Elling et al., 1996). Elling and Duncan (1996) and Smith and Dairiki (1975) demonstrated improved creaming stability with higher phospholipid concentrations.

\section{Viscosity}

Apparent viscosity (hysteresis) curves were produced to describe the flow characteristics of reformulated and natural creams (Figures 1, 2, and 3). Apparent viscosity for most creams was consistent throughout the storage period, so hysteresis curves for d 1 will be discussed. Failing curves represent increasing shear rate and illustrate non-Newtonian behavior. Rising curves illustrate increasing viscosity as shear rate decreases. The higher apparent viscosity values associated with failing curves can be attributed to the breakdown of colloidal aggregate particles as increasing shear is applied during the first stage of viscosity measurement (Fox and McSweeney, 1998).

Figure 1 demonstrates the effect of component separation temperature on apparent viscosity (d 1 of storage) of natural creams and creams containing low-melt fractionated butter oil. Creams processed from components obtained at the $55^{\circ} \mathrm{C}$ separation temperature were higher in viscosity than those processed from components obtained at $49^{\circ} \mathrm{C}$. Within the $55^{\circ} \mathrm{C}$ separation temperature formulations, natural cream was highest in viscosity, followed by cream containing skim milk and low-melt butter oil. Cream formulated with sweet buttermilk, butter-derived aqueous phase and low-melt butter oil was lowest in viscosity. Research conducted by Wibley (1992) and Lee and Sherbon (2002) supports these results. In addition to low-melt fraction butter oil, sweet buttermilk and butter-derived aqueous phase were sources of unsaturated fatty acids. Higher phospholipid and unsaturated fatty acid content (palmitoleic, oleic, and linoleic acid) of the buttermilk and butter-derived aqueous phase may have contributed to increased fluidity of these emulsions (Scott, 1999). 


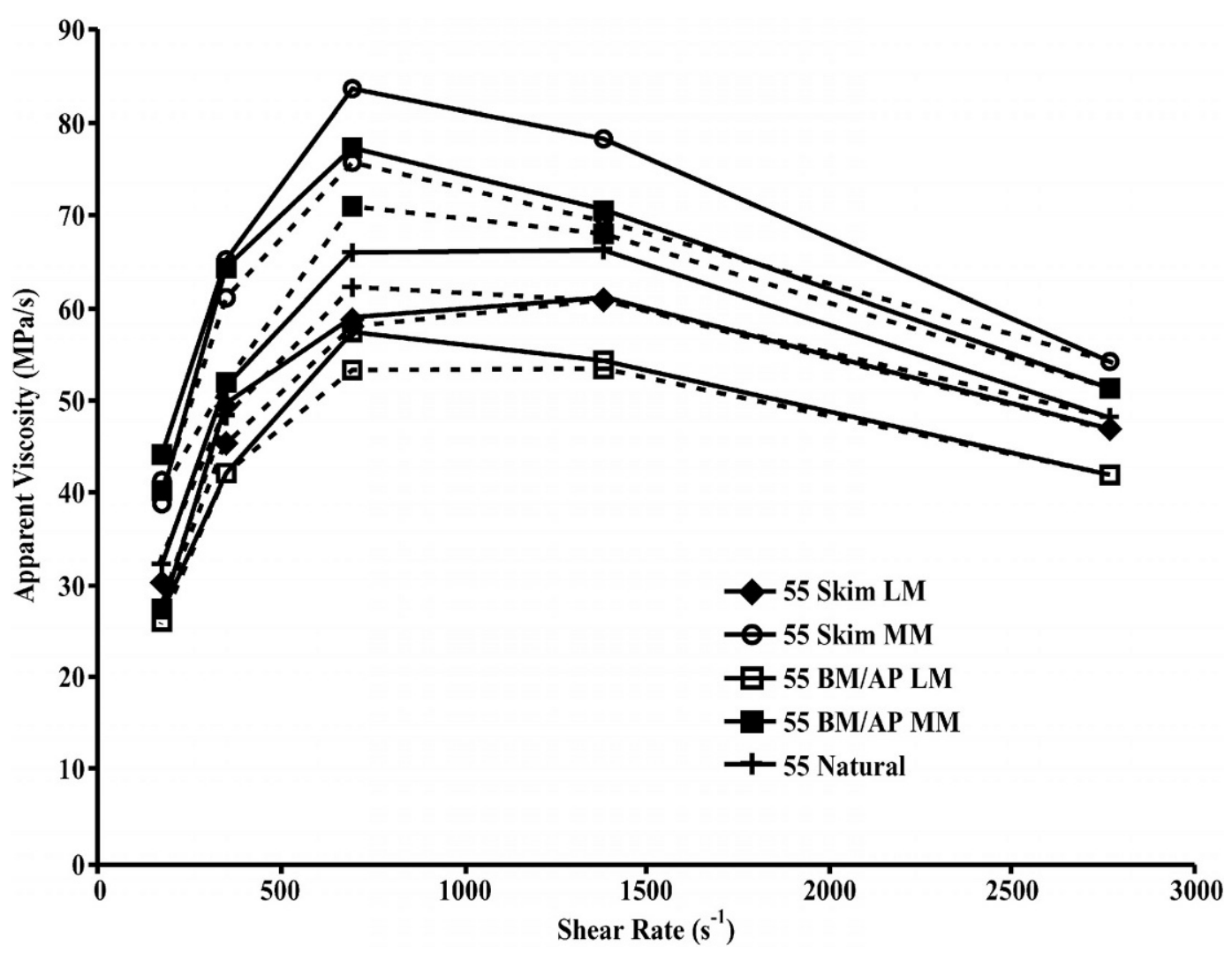

Figure 2. Apparent viscosity of creams formulated with low- (LM) or medium-melting (MM) range butter oil within the $55^{\circ} \mathrm{C}$ separation temperature ( $\mathrm{d} 1$ of storage; $\left.7^{\circ} \mathrm{C}\right)$ (- increasing shear; --- decreasing shear).

Figure 2 compares viscosity of creams formulated from low- and medium-melting range butter oils within the $55^{\circ} \mathrm{C}$ separation temperature. Butter oil characteristics significantly $(P \leq 0.01)$ influenced cream viscosity. Formulations containing components from the $55^{\circ} \mathrm{C}$ separation temperature and low-melt fraction butter oil were significantly less viscous $(P \leq 0.01)$ than those formulated with medium-melt butter oil at a shear rate of $692.48 \mathrm{~s}^{-1}$. At shear rates of $1384.96 \mathrm{~s}^{-1}$ and 2769.92 $\mathrm{s}^{-1}$, creams consisting of skim and low-melt fraction were significantly $(P \leq 0.01)$ lower in viscosity than were the skim/medium-melt butter oil formulated counterparts. The higher saturated fat content of the medium-melt butter oil may have contributed to the higher apparent viscosity in the cream formulations containing this fraction. The medium-melt butter oil contributed more palmitic (29.3\%) and stearic (9.6\%) acid to the creams than did the low-melt fractionated butter oil (19.6 and 8.6\%, respectively) (Kaylegian, 1998). Therefore, creams formulated with medium-melt butter oil were higher in these long-chain saturated fatty acids. The higher levels of saturated fatty acids gave the medium-melting butter oil a more compact, crystalline structure with a higher melting point as compared to the low-melt fraction (Kaylegian, 1998). At $5^{\circ} \mathrm{C}$, the solid fat content of the low-melt butter oil was $35 \%$, whereas the solid fat content of the medium-melt fraction was 63\% (Kaylegian, 1998).

Apparent viscosity was plotted at the shear rate of $692.48 \mathrm{~s}^{-1}$ (because significant effects were observed at this rate) for reformulated and natural creams in order to determine if they remained consistent throughout storage (Figure 3). Apparent viscosity did not fluctuate significantly $(P \geq 0.01)$ during the 13 -d storage period for reformulated creams. However, natural creams increased drastically $(P \leq 0.01)$ in viscosity by day 7 . By d 13 of storage, viscosity of natural cream processed from skim and cream $\left(49^{\circ} \mathrm{C}\right.$ separation) decreased, whereas natural cream processed from skim and cream obtained at $55^{\circ} \mathrm{C}$ continued to increase linearly. Electron micrographs of natural creams $\left(55^{\circ} \mathrm{C}\right.$ separation temperature) show some coalescence that may have contributed to increases in viscosity (data not shown) (Scott, 1999). Over the entire length of storage, reformulated creams manufactured from components obtained at the $55^{\circ} \mathrm{C}$ separation temperature and medium-melt butter oil were highest in viscosity at the shear rate of $692.48 \mathrm{~s}^{-1}$, whereas creams containing low-melt butter 


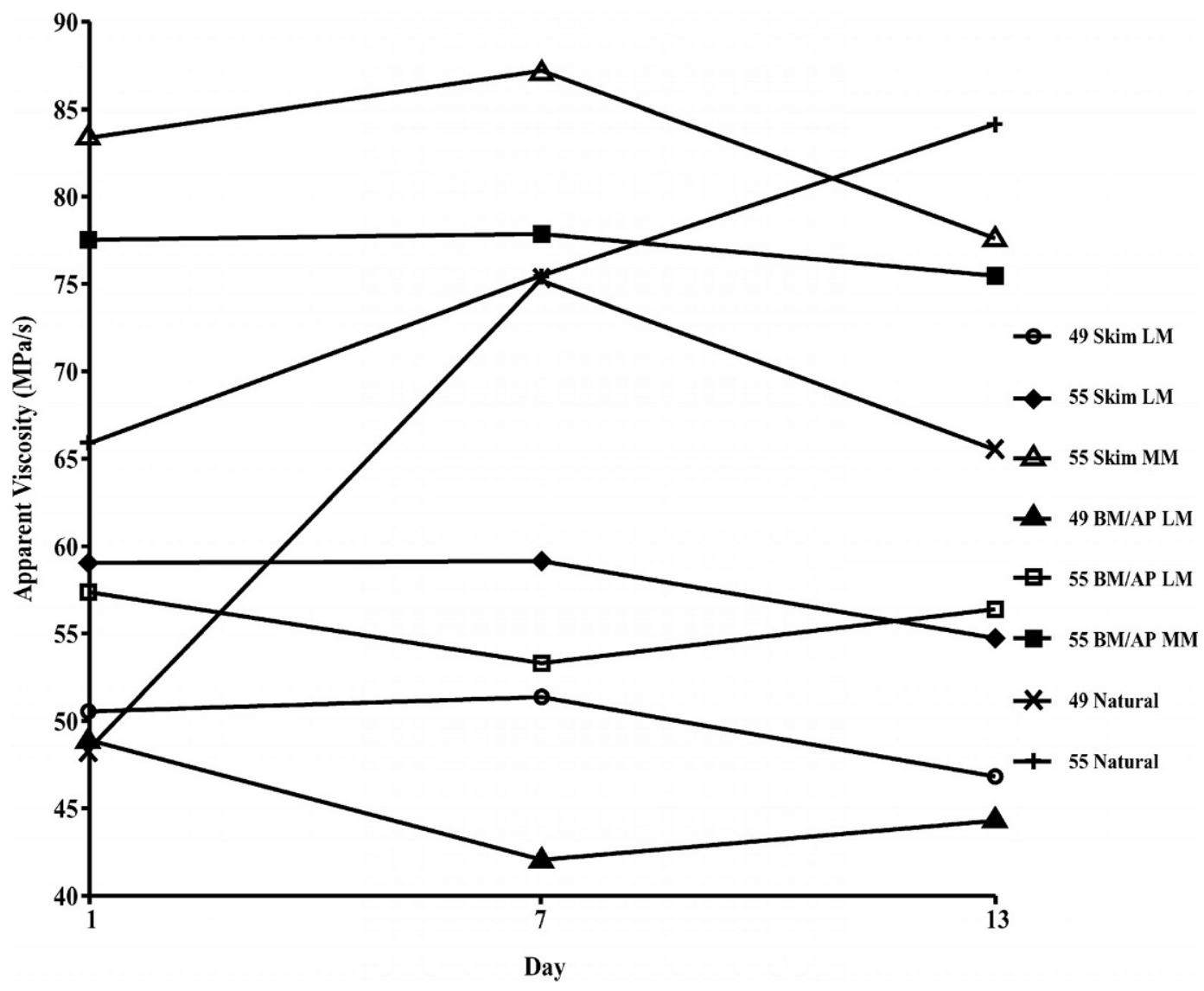

Figure 3. Apparent viscosity ( with low-melt (LM) or medium-melt (MM) butter oil over 2 wk of storage at $3.3^{\circ} \mathrm{C}$.

oil and components obtained at $49^{\circ} \mathrm{C}$ were lowest in viscosity. Those formulations consisting of low-melt butter oil and $55^{\circ} \mathrm{C}$ separation components were intermediate in viscosity at this shear rate.

\section{Feathering Stability}

Intensive processing leads to formation of new protein membranes, which are susceptible to destabilization and flocculation when exposed to heat and acidity. Surface-active composition of formulation components, butter oil characteristics, and component separation temperature could influence feathering characteristics of the creams.

Regardless of formulation, separation temperature used to obtain components, melting range characteristics, and length of storage, the majority of reformulated and natural creams feathered in a $\mathrm{pH}$ range of 4.92 to 5.09. All creams feathered below $\mathrm{pH} 4.92$ and were stable above $\mathrm{pH} 5.20$. Accordingly, feathering scores of 0 to -1 (Anderson et al., 1977) were issued for most creams, and natural and reformulated creams were characterized as moderately stable or slightly unstable. These results are similar to those of Anderson and coworkers (1977), who found that $18 \%$ milk fat, UHT pasteurized creams feathered in a $\mathrm{pH}$ range of 4.70 to 5.20 .

Overall, natural creams were slightly more resistant to feathering than reformulated creams. Creams processed from sweet buttermilk and butter-derived aqueous phase were more comparable to natural creams in incidence of feathering than were creams formulated with skim. Susceptibility to feathering can be related to use of a higher homogenization pressure of 13.6/3.4 $\mathrm{MPa}$ and multiple heat processing steps. During the homogenization process, proteins become adsorbed to lipid globules. Most adsorbed protein, particularly casein and whey, are destabilized by increases in heat and acidity. Use of several heating steps during processing of reformulated and natural creams (i.e., pasteurization of components and creams) probably contributed to sensitivity to denaturation when added to hot buffer solutions. 


\section{Sensory Evaluation of Cream Quality}

Sensory research involving cream and reformulated cream has been minimal. Cream should have a clean, slightly sweet, slightly cooked flavor, and the body and texture should be smooth and free of lumps and fat plugs (Jensen and Poulsen, 1992). The presence of offflavors and poor texture may result from various factors, including low emulsion stability, temperature abuse, processing conditions, and storage conditions.

Efficient pasteurization and subsequent refrigeration yielded acceptable bacterial counts in all creams. The majority of creams were considered to be "In" specification (no off-flavor to slight off-flavor). Texture was not considered in determining acceptability of creams. Apparent viscosity was utilized to evaluate texture. Natural cream processed from components obtained at $55^{\circ} \mathrm{C}$ and creams formulated with sweet buttermilk $\left(55^{\circ} \mathrm{C}\right.$ separation), butter-derived aqueous phase, and low- or medium-melt butter oil were consistently rated "In" specification.

Panelists noted that all creams had a cooked flavor. Cooked flavor is caused by HTST pasteurization of components and creams, resulting in $\mathrm{H}_{2} \mathrm{~S}$ formation. At temperatures above $70^{\circ} \mathrm{C}$, proteins begin to denature, exposing cysteine residues (Fox and McSweeney, 1998). As a result, proteins engage in Maillard browning reactions with lactose, causing the cooked flavor. Panelists used descriptors such as "rich" and "creamy" to characterize the flavor of creams formulated with sweet buttermilk and butter-derived aqueous phase. Natural creams were described as having good dairy flavors. Skim/low-melt butter oil formulations were considered "Out" of specification and were criticized as being oxidized. The low-melt butter oil appeared to be the source of the oxidative flavor characteristics.

Off-flavors caused by oxidation were more pronounced in the low-melting range fractionated butter oil due to the higher content of polyunsaturated fatty acids. The skim/low-melt butter oil formulation was often described as flat in flavor. Sweet buttermilk and butter-derived aqueous phase have many flavor compounds associated with rich and creamy dairy notes, and oxidation of creams formulated with low-melt fraction butter oil emulsified by these components was less perceptible.

\section{CONCLUSIONS}

Customized dairy products provide benefits in targeting niche markets and adding value to the traditional dairy line of product offerings, thereby increasing market share and meeting the changing expectations of the health-conscious consumer population (Duncan, 1998).
Formulation of $20 \%$ milk fat cream with low-melting range, fractionated butter oil yielded a moderately stable, fluid emulsion with lower viscosity than natural cream. Use of the medium-melting range butter oil fraction resulted in cream formulations with a higher viscosity than natural creams and creams formulated with low-melting range butter oil. This characteristic may influence product specifications.

Flavor of the cream was affected when skim milk alone was used as an emulsifying agent, whereas sweet cream buttermilk and butter-derived aqueous phase formulations provided the rich, creamy flavor characteristics expected in cream.

The higher separation temperature used for attaining milk components (particularly skim milk) improved creaming stability and viscosity of reformulated creams. Formulating cream with modified milk fats can provide modified lipid profiles with no influence on quality attributes.

\section{ACKNOWLEDGMENTS}

The authors would like to acknowledge Dairy Management Inc. for funding this project. In addition, appreciation is extended to Grassland Dairy Products Inc. for contribution of commercially processed components and to Wisconsin Center for Dairy Research for the fractionated butter oils. This material is based on work supported by the Cooperative State Research, Education and Extension Service, USDA, under Project No. VA-135552. Any opinions, findings, conclusions, or recommendations expressed in this publication are those of the authors and do not necessarily reflect the view of the USDA.

\section{REFERENCES}

Anderson, M., B. E. Brooker, T. E. Cawston, and G. C. Cheeseman. 1977. Changes during storage in stability and composition of ultra-heat-treated aseptically-packed cream of $18 \%$ fat content. J. Dairy Res. 44:111-123.

Atherton, H. V., and J. A. Newlander. 1977. Chemistry and Testing of Dairy Products. Avi Publishing Co., Inc., Westport, CT.

Deeney, J. T., H. M. Valivullah, C. H. Dapper, D. P. Dylewski, and T. W. Keenan. 1985. Microlipid droplets in milk secreting mammary epithelial cells: Evidence that they originate from endoplasmic reticulum and are precursors of milk lipid globules. Eur. J. Cell Biol. 38:16-26.

Duncan, S. E. 1998. Dairy products: The next generation. Altering the image of dairy products through technology. J. Dairy Sci. 81:877-883.

Elling, J. L., S. E. Duncan, T. W. Keenan, W. N. Eigel, and J. Boling. 1996. Composition of $20 \%$ reformulated creams manufactured from reduced cholesterol butter oil. J. Food Sci. 61:48-53.

Elling, J. L., and S. E. Duncan. 1996. Physical properties of $20 \%$ milk fat reformulated creams manufactured from cholesterol-reduced butter oil. J. Food Sci. 61:375-378.

Fox, P. F., and P. L. H. McSweeney. 1998. Dairy Chemistry and Biochemistry. Blackie Academic and Professional Press, London, U.K. 
Geyer, S., and H. G. Kessler. 1989. Effect of manufacturing methods on the stability to feathering of homogenized UHT coffee cream. Milchwissenschaft 44:423-427.

Houlihan, A. V., P. A. Goodard, S. M. Nottingham, B. J. Kitchen, and C. J. Masters. 1992. Interactions between the bovine milk fat globule membrane and skim milk components on heating whole milk. J. Dairy Res. 59:187-195.

Jensen, G. K., and H. H. Poulsen. 1992. Sensory Aspects. Pasteurization of Cream. In Bull. Int. Dairy Fed. \#271, Brussels, Belgium.

Jeurnink, T. J. M., and K. G. De Kruif. 1993. Changes in milk on heating: Viscosity measurements. J. Dairy Res. 60:139-150.

Kaylegian, K. E. 1995. Functional characteristics and nontraditional applications of milk lipid components in food and nonfood systems. J. Dairy Sci. 78:2524-2540.

Kaylegian, K. E. 1998. Technical Data Sheet of Experimental Milkfat Fractions. Wisconsin Center for Dairy Res., Univ. of Wisconsin, Madison.

Kaylegian, K. E., and R. C. Lindsay. 1992. Performance of selected milk fat fractions in cold-spreadable butter. J. Dairy Sci. 75:3307-3317.

Kaylegian, K. E., and R. C. Lindsay. 1995. Handbook of Milkfat Fractionation Technology and Applications. AOCS Press, Champaign, IL.

Keenan, T. W., and S. Patton. 1993. The milk lipid globule membrane. In Handbook of Milk Composition. R. G. Jensen and M. P. Thompson, ed. Academic Press, New York, NY.

Kim, H., and R. Jimenez-Flores. 1995. Heat-induced interactions between the proteins of milk fat globule membrane and skim milk. J. Dairy Sci. 78:24-35.

Langley, K. R. 1984. Changes in viscosity of processed creams during storage at $5^{\circ} \mathrm{C}$. J. Dairy Res. 51:299-305.

Lee, J. L., and J. W. Sherbon. 2002. Chemical changes in bovine milk fat globule membrane caused by heat treatment and homogenization of whole milk. J. Dairy Res. 69:555-567.

Marshall, R. T. 1993. Standard Methods for the Examination of Dairy Products. 16th ed. Am. Public Health Assoc., Inc., Washington, DC
McCrae, C. H., A. J. R. Law, and J. Leaver. 1999. Emulsification properties of whey proteins in their natural environment: Effect of whey protein concentration at 4 and $18 \%$ milk fat. Food Hydrocoll. 13:389-399.

McPherson, A. V., M. C. Dash, and B. J. Kitchen. 1984. Isolation and composition of milk fat globule membrane material. II. From homogenized and ultra heat treated milks. J. Dairy Res. $51: 289-297$.

Melsen, J. P., and P. Walstra. 1989. Stability of recombined milk fat globules. Neth. Milk Dairy J. 43:63-78.

Munoz, A. M., G. V. Civille, and B. T. Carr. 1992. Sensory Evaluation in Quality Control. Van Nostrand Reinhold, New York, NY.

Oortwijn, H., and P. Walstra. 1979. The membranes of recombined fat globules. 2. Composition. Neth. Milk Dairy J. 31:134-147.

Phipps, L. W. 1982. A viscometric study of the flocculation of the components in stored homogenized ultra-heat-treated cream. J. Dairy Res. 49:655-664.

Prentice, J. H. 1972. Rheology and texture of dairy products. J. Texture Studies 3:415-458.

Prentice, J. H. 1992. Dairy Rheology. A Concise Guide. VCH Publishers, Inc., New York, NY.

Scott, L. L. 1999. The effect of milkfat melting properties on chemical and physical properties of $20 \%$ reformulated cream. M.S. Thesis, Virginia Polytechnic Institute and State Univ., Blacksburg.

Smith, L. M., and T. Dairiki. 1975. Stability of milk fat emulsions. II. Influence of emulsifier structure, sodium caseinate, and nonfat milk solids. J. Dairy Sci. 58:1254-1262.

Tomas, A., D. Paquet, J. L. Courthaudon, and D. Lorient. 1994. Effect of fat and protein contents on droplet size and surface protein coverage in dairy emulsions. J. Dairy Sci. 77:413-417.

Towler, C. 1982. Cream products for the consumer. N. Z. J. Dairy Sci. Technol. 17:191-202.

Wibley, A. 1992. Homogenization. J. Soc. Dairy Technol. 45:31-32.

Yamauchi, K., M. Shimizu, and T. Ando. 1982. Milk fat globule membrane proteins in aseptically packaged ultra-heat-treated milk: Changes during storage. Agric. Biol. Chem. 46:823-825. 